Article

\title{
Desorption of Furfural from Bimetallic Pt-Fe Oxides/Alumina Catalysts
}

\author{
Gloria Lourdes Dimas-Rivera ${ }^{1}$, Javier Rivera de la Rosa ${ }^{1,3, *}$, Carlos J. Lucio-Ortiz ${ }^{1}$,*, \\ José Antonio De los Reyes Heredia ${ }^{2}$, Virgilio González González ${ }^{3}$ and Tomás Hernández ${ }^{1}$ \\ 1 Universidad Autónoma de Nuevo León, UANL, Facultad de Ciencias Químicas, \\ Ave. Universidad S/N, Cd. Universitaria, San Nicolás de los Garza, N.L. 64451, Mexico; \\ E-Mails: gloria.dimasrvr@uanl.edu.mx (G.L.D.-R.); tomas.hernandezgr@uanl.edu.mx (T.H.) \\ 2 Universidad Autónoma Metropolitana Iztapalapa, Departamento de Ingeniería Química, \\ Mexico, D.F. 09340, Mexico; E-Mail: jarh@xanum.uam.mx \\ 3 Universidad Autónoma de Nuevo León, UANL, Centro de Innovación, Investigación y Desarrollo \\ en Ingeniería y Tecnología (CIIDIT), Km 10 de la nueva carretera al Aeropuerto Internacional de \\ Monterrey, PIIT Monterrey, Apodaca, Nuevo León 66600, Mexico; \\ E-Mail: virgilio.gonzalezgnz@uanl.edu.mx
}

* Authors to whom correspondence should be addressed; E-Mails: javier.riverad@ uanl.edu.mx (J.R.R.); carlos.lucioor@uanl.edu.mx (C.J.L.-O.); Tel.: +52-818-329-4000 (ext. 6281) (J.R.R.); Fax: +52-818-329-4000 (ext. 6282) (J.R.R.).

Received: 14 October 2013; in revised form: 10 January 2014 / Accepted: 13 January 2014 / Published: 20 January 2014

\begin{abstract}
In this work, the desorption of furfural, which is a competitive intermediate during the production of biofuel and valuable aromatic compounds, was studied using pure alumina, as well as alumina impregnated with iron and platinum oxides both individually and in combination, using thermogravimetric analysis (TGA). The bimetallic sample exhibited the lowest desorption percentage for furfural. High-resolution transmission electron microscopy (HRTEM) imaging revealed the intimate connection between the iron and platinum oxide species on the alumina support. The mechanism of furfural desorption from the $\mathrm{Pt}-\mathrm{Fe} / \mathrm{Al}_{2} \mathrm{O}_{3} \quad 0.5 \%-0.5 \%$ sample was determined using physisorbed furfural instead of chemisorbed furfural; this mechanism involved the oxidation of the $\mathrm{C}=\mathrm{O}$ group on furfural by the catalyst. The oxide nanoparticles on $\gamma-\mathrm{Al}_{2} \mathrm{O}_{3}$ support helped to stabilize the furfural molecule on the surface.
\end{abstract}


Keywords: furfural; bimetallic; Pt-Fe; desorption; impregnation; $\gamma-\mathrm{Al}_{2} \mathrm{O}_{3}$

\section{Introduction}

Furfural can be transformed into several important chemical products by hydrogenation, oxidation, reductive amination, decarboxilation, nitration and condensation [1,2]. For example, furfural can be decarbonylated to yield furan, which is used to synthesize valuable aromatic compounds $[3,4]$. Also, furfurals are important intermediates in the sequences that are being investigated to produce biofuels [1-7]. Therefore, it is important to study furfural adsorption over catalysts to analyze the interaction between the molecule and the surface of the catalyst. Moreover, the chemical steps involved in heterogeneous catalysis imply reactive adsorption, reaction over the surface of the catalyst, and product desorption towards the reacting environment [8].

Bimetallic catalysts have garnered considerable interest and continued investigation because they often exhibit improved catalytic activity and selectivity in heterogeneous reactions relative to their monometallic counterparts [9-11]. In Addition, to understand the origins of the novel catalytic properties, bimetallic surfaces show electronic and chemical properties that are distinct from those of their parent metals, which offer enhanced selectivity, activity, and stability [12]. Furfural is hydrogenated to obtain furfuryl alcohol using the bimetallic $\mathrm{Pt} / \mathrm{Sn}$ and $\mathrm{Pt} / \mathrm{Ge}$ catalysts supported on silica [13]. Notably, both metals interact with the surface support but remain unaffected by the specific area, acidity or metal dispersion [14] because the interaction between the metal and the support or promoter may facilitate the adsorption of reactants, contributing to the high furfural conversion and the high selectivity for furfuryl alcohol formation [15]. Adding FeOx to a $\gamma$-alumina support enhanced the catalytic activity of pure $\gamma$-alumina [16]. Incorporating Fe nanoparticles as a second metal on the alumina improves the sorption/catalytic characteristics with other nanoparticles, such as $\mathrm{Pd}$ and Pt [17-20]. In this work, a bimetallic Fe-Pt oxide/ $\gamma$-alumina catalyst has been synthesized to test its desorption interactions with furfural.

\section{Results and Discussion}

\section{1. $N_{2}$ Physisorption}

The $\mathrm{N}_{2}$ adsorption-desorption isotherms for the samples at $-196{ }^{\circ} \mathrm{C}$ exhibit type IV isotherms, according to the IUPAC classifications, with a typical hysteresis loop due to the capillary condensation of nitrogen into the mesopores [21-23] (data not shown). The specific surface area of the alumina and the catalysts after calcinating at $600{ }^{\circ} \mathrm{C}$ are presented in Table 1 . The $\gamma$-alumina decreases in specific surface area from 244.15 to $195.88 \mathrm{~m}^{2} / \mathrm{g}$ after calcination at $600{ }^{\circ} \mathrm{C}$. In comparison with the uncalcined alumina, the Fe-impregnated catalyst the area decreases just $10 \%$, but when it is impregnated with $\mathrm{Pt}$ it decreases 27\%; this is due to the Pt particles which block more pores than Fe oxide particles and a stronger interaction of $\mathrm{Pt}$ particles with the $\gamma$-alumina can be suspected. The bimetallic catalyst has a lower surface area than the rest of the catalysts due to the higher amount of $\mathrm{Pt}$ and Fe particles together that have blocked the alumina pores [23-26]. The interactions between the metals and the catalyst can 
be observed in temperature-programmed reduction (TPR). However, after calcination, the alumina has a lower surface area than the Fe-impregnated catalyst because the impregnated particles prevent the alumina from sintering or compacting, forming more pores in the surface.

Table 1. Textural properties and weight percent of metals in the catalysts.

\begin{tabular}{cccccc}
\hline \multirow{2}{*}{ Sample } & \multicolumn{2}{c}{$(\%)$} & $\begin{array}{c}\text { Surface } \\
\text { area }\left(\mathrm{m}^{2} / \mathrm{g}\right)\end{array}$ & $\begin{array}{c}\text { Average pore } \\
\text { diameter }(\mathbf{n m})\end{array}$ & Average pore volume $(\mathbf{c c} / \mathbf{g})$ \\
\cline { 2 - 4 } & $\mathbf{F e}$ & $\mathbf{P t}$ & & \\
\hline $\mathrm{Alumina} *$ & - & - & 196 & 8.83 & 0.43 \\
$\mathrm{Fe} / \mathrm{Al}_{2} \mathrm{O}_{3} 0.5 \%$ & 0.44 & - & 218 & 8.40 & 0.46 \\
$\mathrm{Pt} / \mathrm{Al}_{2} \mathrm{O}_{3} 0.5 \%$ & - & 0.60 & 177 & 9.31 & 0.41 \\
$\mathrm{Pt}-\mathrm{Fe} / \mathrm{Al}_{2} \mathrm{O}_{3} 0.5 \%-0.5 \%$ & 0.43 & 0.47 & 169 & 9.56 & 0.40 \\
\hline \multicolumn{6}{c}{$*$ Calcination at $600{ }^{\circ} \mathrm{C}$}
\end{tabular}

\subsection{SEM and HRTEM Images}

Figure 1 presents the scanning electron photomicrographs for the samples containing platinum and iron on alumina ( $\mathrm{Pt}-\mathrm{Fe} / \mathrm{Al}_{2} \mathrm{O}_{3}$ 0.5\%-0.5\%). The Scanning electronic microscopy (SEM) image reveals that the nanoparticles are dispersed on the alumina surface. Several of these nanoparticles are agglomerated, forming 300 to $600 \mathrm{~nm}$ structures, while the smaller individual nanoparticles are $\sim 30 \mathrm{~nm}$ tetragonal prisms and they are observed on the contours of the alumina grains. Figure 2a displays a scanning transmission electron microscopy (STEM) image of an individual alumina grain with nanoparticles deposited on its surface. More nanoparticles are observed as individuals rather than in aggregates. The flat faces of some of the nanoparticles are very clear, forming almost perfect tetragonal prisms from 10 to $60 \mathrm{~nm}$ in size. The other nanoparticles have an ellipsoid shape with slightly deformed and softened contours. These types of nanoparticles range in size from $5 \mathrm{~nm}$ individuals to $26 \mathrm{~nm}$ agglomerates. The tetragonal nanoparticles are associated with the platinum oxide species [27], while the ellipsoid shapes are associated with the iron oxide species [16,28-30]. Although a wide particle size distribution was achieved, good dispersion was obtained.

Figure 1. SEM image of $\mathrm{Pt}-\mathrm{Fe} / \mathrm{Al}_{2} \mathrm{O}_{3} 0.5 \%-0.5 \%$.

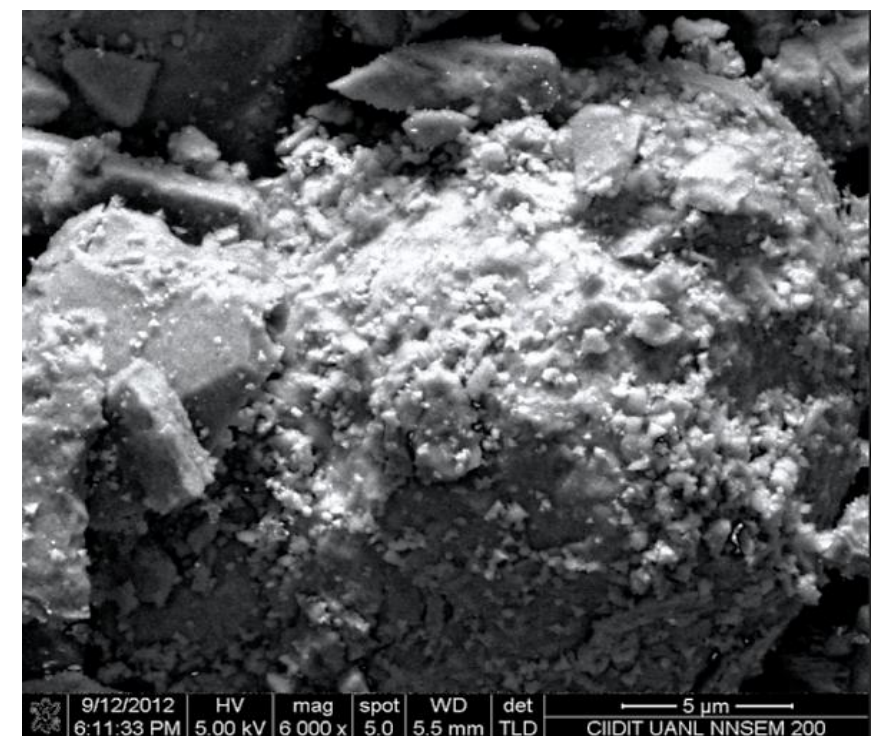


Figure $2 \mathrm{~b}$ provides a high-resolution TEM (HRTEM) image and its Fourier-transformed micrograph (FTM) inset. Perpendicular lines are drawn to identify the interplanar distances (IDs) in the micrographs, and the average is reported. The structures are identified using the Joint Committee on Powder Diffraction Standards (JCPDS). The $0.30 \pm 0.03 \mathrm{~nm}$ ID is correlated with the (220) plane of the magnetite phase $\left(\mathrm{Fe}_{3} \mathrm{O}_{4}\right)$, according to JCPDS 82-1533, or the (220) plane of the maghemite phase $\left(\gamma-\mathrm{Fe}_{2} \mathrm{O}_{3}\right)$, according to JCPDS 24-0081. The $0.27 \pm 0.05 \mathrm{~nm}$ ID is correlated with the (221) plane of the magnetite phase (JCPDS 24-0081) or the (104) plane of the hematite phase $\left(\alpha-\mathrm{Fe}_{2} \mathrm{O}_{3}\right)$, according to JCPDS 86-0550; the $0.22 \pm 0.04 \mathrm{~nm}$ ID is correlated with the (113) plane of the hematite phase. The two IDs at $0.21 \pm 0.03 \mathrm{~nm}$ and $0.21 \pm 0.02 \mathrm{~nm}$ are correlated with the (110) plane of the PtO (JCPDS 01-085-0714), the $0.24 \pm 0.03 \mathrm{~nm}$ ID corresponds to the (012) plane of the $\mathrm{Pt}_{6} \mathrm{O}_{8}$ species (JCPDS 96-100-8966) and the $0.20 \pm 0.01 \mathrm{~nm}$ ID is correlated to the (202) plane of the hematite phase. Different platinum and iron oxides are intimately connected on the alumina support. In the FTM, the (202) and (012) planes for hematite and $\mathrm{Pt}_{6} \mathrm{O}_{8}$ are also identified. Figure $2 \mathrm{c}$ displays the select area diffraction pattern (SADP) as the rings for the (422) plane for magnetite and the (731) plane for hematite. The (031) plane corresponds to the $\mathrm{PtO}_{2}$ phase (JCPDS 01-073-2361), and the (211) plane corresponds to the $\alpha-\mathrm{PtO}_{2}$ phase (JCPDS 00-038-1355).

Figure 2. (a) STEM image of a grain of $\mathrm{Al}_{2} \mathrm{O}_{3}$ with $\mathrm{Pt}-\mathrm{Fe}$ oxide nanoparticle; (b) high-resolution transmission electron microscopy (HRTEM) image and its Fourier transformed micrograph and (c) select area diffraction pattern (SADP) of the same sample.

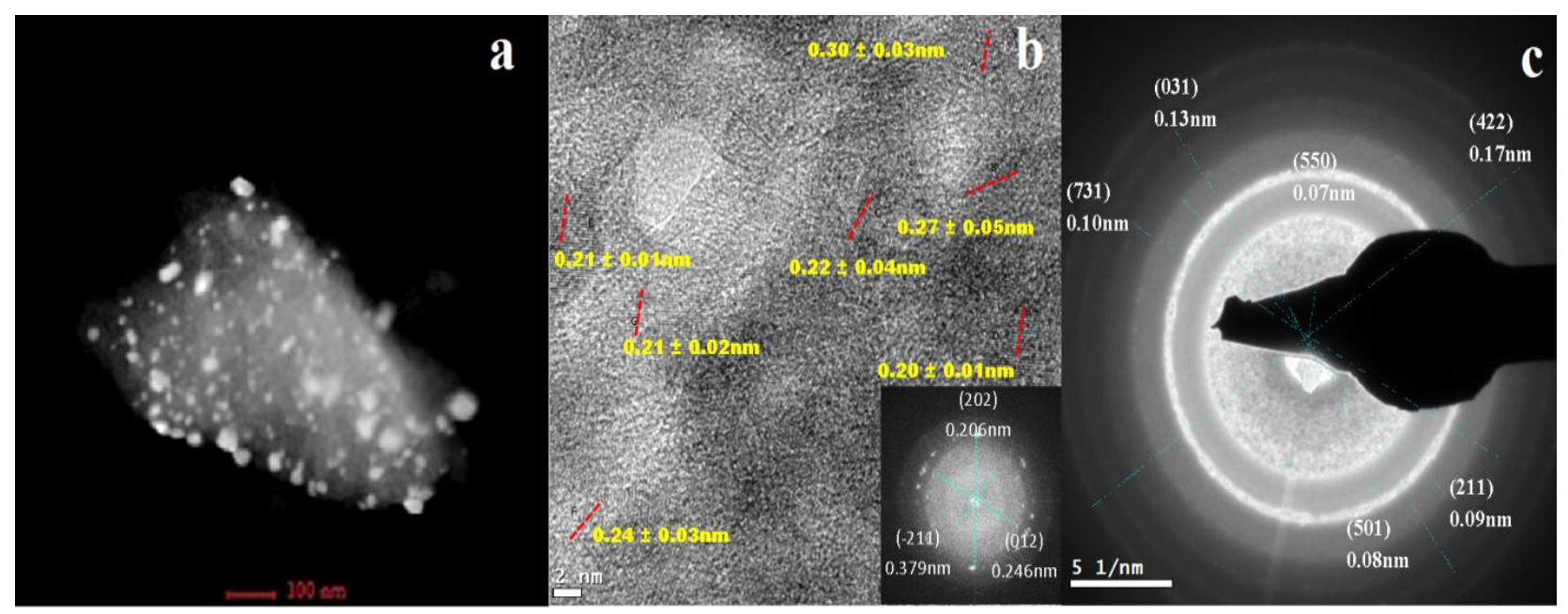

\subsection{FT-IR Catalyst Studies}

Figure 3 displays the FT-IR spectra for pure alumina, as well as alumina impregnated with the following: $0.5 \% \mathrm{Fe}, 0.5 \% \mathrm{Pt}$ and $0.5 \%$ of both $\mathrm{Pt}$ and Fe. Figure $3 \mathrm{a}$ focuses on the 3900 to $2300 \mathrm{~cm}^{-1}$ region that contains the bands ascribed to the $\mathrm{OH}$ groups from the alumina; this band is very pronounced in the pure alumina, but decreases when metal is present on the support to become much lower when $\mathrm{Pt}$ is present. Figure $3 \mathrm{~b}$ reveals the presence of the $\mathrm{CO}$ species adsorbed on the $\mathrm{Pt}$ in the range of 2050-2150 $\mathrm{cm}^{-1}[31,32]$. For the pure alumina and $\mathrm{Fe} / \mathrm{Al}_{2} \mathrm{O}_{3} 0.5 \%$ samples do not display any bands in this range. In the $\mathrm{Pt} / \mathrm{Al}_{2} \mathrm{O}_{3} 0.5 \%$ sample, the weak band at $2111 \mathrm{~cm}^{-1}$ is attributed to the $\mathrm{Pt}(\mathrm{III})(\mathrm{CO})_{2}$ species [32,33]; these species are formed because the $\mathrm{Pt}$ adsorbs the $\mathrm{CO}$ from the 
surrounding environment; in the Pt-Fe/ $/ \mathrm{Al}_{2} \mathrm{O}_{3} \quad 0.5 \%-0.5 \%$ sample, this signal is shifted toward a lower energy $\left(2109 \mathrm{~cm}^{-1}\right)$. There is a series of typical signals attributed to $\mathrm{CO}$ species adsorbed on platinum [31-35] in both of the samples containing platinum; some of these signals are observed at the same wavenumber, while others are slightly shifted.

Figure 3. FT-IR spectra in the (a) 2300-3900 cm (c) 350-1750 $\mathrm{cm}^{-1}$ : regions for the alumina (-), $\mathrm{Fe} / \mathrm{Al}_{2} \mathrm{O}_{3} 0.5 \%(-), \mathrm{Pt} / \mathrm{Al}_{2} \mathrm{O}_{3} 0.5 \%(-)$ and $\mathrm{Pt}-\mathrm{Fe} / \mathrm{Al}_{2} \mathrm{O}_{3} 0.5 \%-0.5 \%(-)$ samples.

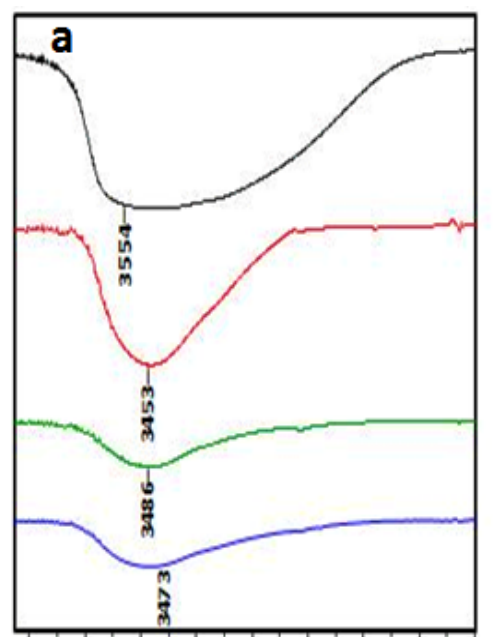

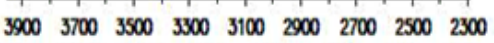
wavenumber $\left(\mathrm{cm}^{-1}\right)$

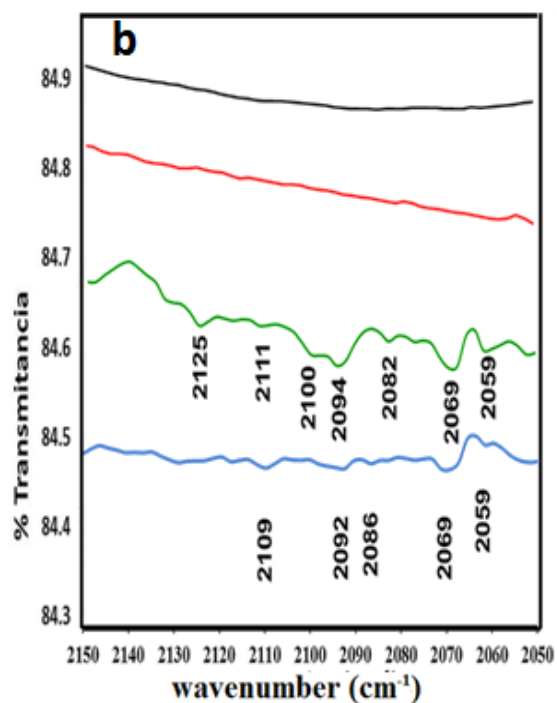

wavenumber $\left(\mathrm{cm}^{-1}\right)$

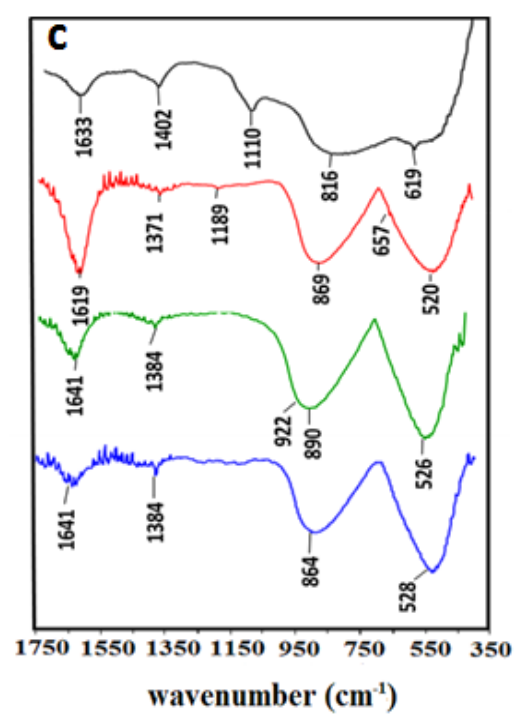

From 350 to $1750 \mathrm{~cm}^{-1}$, as displayed in Figure $3 \mathrm{c}$, the pure alumina band at $1633 \mathrm{~cm}^{-1}$ is characteristic of the $\mathrm{H}-\mathrm{O}$ bending mode due to the deformed vibration mode of chemisorbed water [36]. For the samples containing platinum, this band is shifted to $1641 \mathrm{~cm}^{-1}$ due to the higher vibrational coupling energy of the $\mathrm{H}-\mathrm{O}$ functional group. In contrast, this signal was detected at a lower energy $\left(1619 \mathrm{~cm}^{-1}\right)$ for the $\mathrm{Fe} / \mathrm{Al}_{2} \mathrm{O}_{3}$ sample. In this case, the interaction between the oxide species and the $\mathrm{O}-\mathrm{H}$ functional groups may be affected by the Brønsted acidic sites on the alumina. The bands arising from the pure alumina sample at 1408 and $1110 \mathrm{~cm}^{-1}$ may be attributed to the remnants of the commercial alumina precursors [16,37]. According to the current literature, the presence of Pt (II) is indicated by the signal at $\sim 922 \mathrm{~cm}^{-1}$ [33], but this band overlaps with a band assigned to the alumina. The stronger, broader bands at $816 \mathrm{~cm}^{-1}$ and $619 \mathrm{~cm}^{-1}$ correspond to the vibrations of the $\mathrm{AlO}_{4}$ tetrahedra and the $\mathrm{AlO}_{6}$ octahedra, respectively, in the pure $\gamma-\mathrm{Al}_{2} \mathrm{O}_{3}$ sample [16,37]. The impregnation with the oxides shifts the tetrahedral band to a higher vibrational energy, while the octahedral band migrates to lower values; therefore, there is a stronger interaction with the tetrahedral sites. The presence of the Pt oxide species generates shoulder peaks at low energies (426 and $410 \mathrm{~cm}^{-1}$ ), and the iron oxide species has only a weak shoulder at $657 \mathrm{~cm}^{-1}$ that may be correlated to the maghemite phase [38]. 


\subsection{Temperature Programmed Reduction}

Figure 4 presents the TPR traces for the bi- and monometallic $\gamma-\mathrm{Al}_{2} \mathrm{O}_{3}$ catalysts, calcined at $600{ }^{\circ} \mathrm{C}$. The calcined $\gamma-\mathrm{Al}_{2} \mathrm{O}_{3}$ does not have a reduction peak. However, two reduction peaks at 580 and $922{ }^{\circ} \mathrm{C}$ can be observed for $\mathrm{Fe} / \mathrm{Al}_{2} \mathrm{O}_{3}$. The first signal is attributed to the reduction of the $\mathrm{Fe}_{2} \mathrm{O}_{3}$ to $\mathrm{Fe}_{2} \mathrm{O}_{3}$ and the second peak is attributed to the reduction of the $\mathrm{Fe}_{2} \mathrm{O}_{3}$ to $\mathrm{FeO}+\mathrm{Fe}$ [39-41]. The TPR profile of the monometallic Pt catalysts reveals a reduction peak at $427{ }^{\circ} \mathrm{C}$ corresponding to Pt oxy- or hydroxychlorinated species being reduced to elemental Pt $[42,43]$. A reduction peak similar to that for the Pt catalyst but less intense is observed for the bimetallic Pt-Fe catalysts. Researchers have observed that the presence of $\mathrm{Pt}$ in bimetallic catalysts promotes the reduction of the other metal; therefore, the reduction peak is shifted toward lower temperatures due to increased metal-metal versus metal-support interactions $[42,43]$. For example, the Ge oxide species are reduced at $600{ }^{\circ} \mathrm{C}$, but $\mathrm{Pt}$ incorporation lowers the reduction temperature to $315^{\circ} \mathrm{C}$ [42]. Another interesting feature of the bimetallic oxide TPR results is the presence of only one reduction signal, compared to the two peaks observed for the Fe catalyst. The appearance of a single TPR peak shows that the reduction of two metal oxides is essentially simultaneous, and an alloy is formed. This phenomenon is a common evidence to judge the formation of alloy in the bimetallic catalyst $[44,45]$. The TPR results agree with HRTEM data because both indicate that there is a strong interaction between the $\mathrm{Pt}$ and $\mathrm{Fe}$, which is characteristic of alloys. TPR results also agree with HRTEM; different Pt and Fe species are present with different shapes, sizes and structures across the surface of the catalyst. The Fe is present as maghemite, magnetite and hematite, while $\mathrm{Pt}$ is observed as oxides and coordinated species. In addition, the peak for the $\mathrm{Pt}-\mathrm{Fe} / \mathrm{A}_{2} \mathrm{O}_{3}$ catalyst is slightly less pronounced than the peak for the $\mathrm{Pt} / \mathrm{Al}_{2} \mathrm{O}_{3}$. The reduction temperature for this alloy is lower than Fe reduction temperature, indicating that the alloy particle size decreases due to the increasing particle dispersion that reduces the $\mathrm{H}_{2}$ consumption, according to reports by Pojanavaraphan et al. [46].

Figure 4. Temperature-programmed reduction (TPR) of alumina (-); $\mathrm{Fe} / \mathrm{Al}_{2} \mathrm{O}_{3} 0.5 \%(-)$; $\mathrm{Pt} / \mathrm{Al}_{2} \mathrm{O}_{3} 0.5 \%$ (一) and Pt-Fe/ $/ \mathrm{Al}_{2} \mathrm{O}_{3} 0.5 \%-0.5 \%$ (一) substrates.

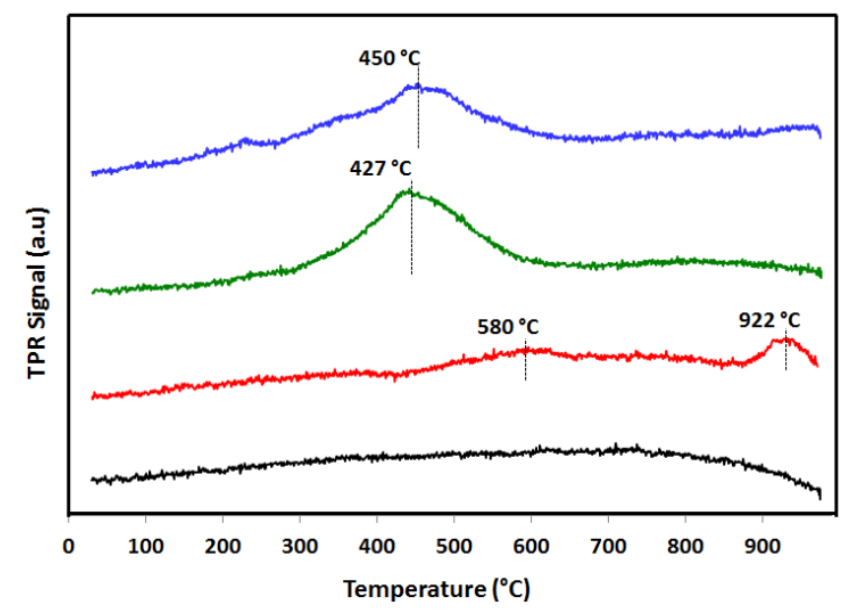




\subsection{TGA Desorption}

Figure 5a displays the thermogravimetric data in which the pure alumina has a higher furfural desorption than the doped alumina. All the catalysts (with and without furfural impregnation) were analyzed by TGA. For the catalysts without furfural, no water is released; therefore, water does not interfere with the analysis of furfural desorption. In the differential thermal analysis (Figure 5b), a slight endothermic change is observed below $100{ }^{\circ} \mathrm{C}$. However, this signal does not represent a considerable chemical event; instead, it reveals a physical interaction between the catalyst and the furfural. Table 2 lists the steps of the thermogravimetric data with the weight loss percentage (WLP). In the first step, the pure alumina and $\mathrm{Fe} / \mathrm{Al}_{2} \mathrm{O}_{3} 0.5 \%$ samples present a $\geq 10 \%$ WLP. The $\mathrm{Pt} / \mathrm{Al}_{2} \mathrm{O}_{3}$ $0.5 \%$ sample displays a $6.7 \%$ WLP, while the $\mathrm{Pt}-\mathrm{Fe} / \mathrm{Al}_{2} \mathrm{O}_{3} \quad 0.5 \%-0.5 \%$ sample loses only $5 \%$. During the second step, all of the samples lose more than $11 \%$, except for the $\mathrm{Pt}-\mathrm{Fe} / \mathrm{Al}_{2} \mathrm{O}_{3} 0.5 \%-0.5 \%$ sample that loses only $10.8 \%$. Some investigators have determined the furfural desorption in different materials: Zhang et al. [4] studied furfural desorption in $\mathrm{K}$ doped $\mathrm{Pd} / \mathrm{Al}_{2} \mathrm{O}_{3}$ catalysts using programmed temperature up to $600{ }^{\circ} \mathrm{C}$ to observe only a single, intense desorption signal at $67{ }^{\circ} \mathrm{C}$; Vorotnikov et al. [47] reported that molecular furfural desorption begins around $-13{ }^{\circ} \mathrm{C}$ to complete by $187^{\circ} \mathrm{C}$ after peaking at $\sim 92{ }^{\circ} \mathrm{C}$ using temperature-programmed desorption (TPD) data, and the breadth of the desorption peak indicated that different adsorption states also desorb furfural, generating different molecular decomposition reactions after increased exposure; Pang et al. [48] found that furfural molecular desorption occurs at $\sim 102{ }^{\circ} \mathrm{C}$. During our TGA tests, the iron and platinum oxides in the bimetallic catalyst presented a higher furfural adsorption strength because they release approximately $13.7 \%$ of the furfural at $495{ }^{\circ} \mathrm{C}$, while other samples released more than $14.7 \%$. The DTA results do not indicate that there was any chemical event during the desorption process; indicating that the furfural adsorption states are stable intermediates that prevent the decomposition.

Figure 5. (a) Thermogravimetric analysis (TGA) and (b) DTA of furfural on different substrates: alumina (-), $\mathrm{Fe} / \mathrm{Al}_{2} \mathrm{O}_{3} 0.5 \%$ (-), $\mathrm{Pt} / \mathrm{Al}_{2} \mathrm{O}_{3} 0.5 \%$ (-) and $\mathrm{Pt}-\mathrm{Fe} / \mathrm{Al}_{2} \mathrm{O}_{3}$ $0.5 \%-0.5 \%(-)$.
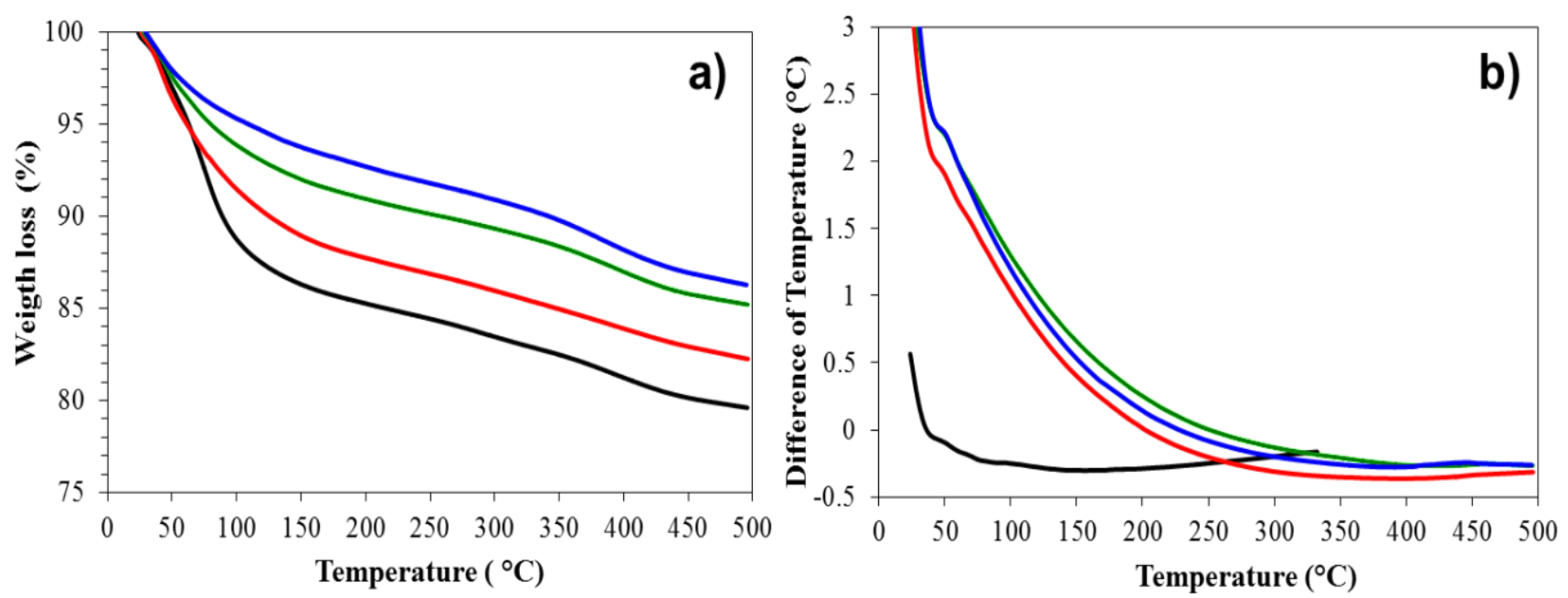
Equation (1) is a kinetic model of an organic molecule desorption:

$$
\mathrm{d} \alpha / \mathrm{d} t=k(T) f(\alpha)
$$

where $\alpha=\left(w_{0}-w_{t}\right) /\left(w_{0}-w_{f}\right), w_{t}$ is the mass at time $t ; w_{0}$ is the initial mass and $w_{f}$ is the mass at the last temperature from the test, $500{ }^{\circ} \mathrm{C}$. The kinetic constant follows the Arrhenius equation:

$$
\mathrm{d} \alpha / \mathrm{d} t k(T)=k_{0} \exp \left(-E_{a} / \mathrm{R} T\right)
$$

where $k_{0}$ is the pre-exponential factor; $\mathrm{R}$ is the gas constant; $T$ is the temperature and $E_{a}$ is the apparent activation energy. The form of $f(\alpha)$ can be expressed as follows:

$$
f(\alpha)=(1-\alpha)^{n} \alpha^{m}[\ln (1-\alpha)]^{p}
$$

where the exponential values of $m$ and $p$ are considered equal to zero, according to other desorption-degradation studies of organic samples [49]. Assuming that the reactions engaged during the desorption process are first order, Equation (1) can be written as follows:

$$
\mathrm{d} \alpha / \mathrm{d} t=k_{0} \exp \left(-E_{a} / \mathrm{R} T\right)(1-\alpha)
$$

Table 2. Thermogravimetric data at collected at $10{ }^{\circ} \mathrm{C} / \mathrm{min}$ under $\mathrm{N}_{2}(15 \mathrm{~mL} / \mathrm{min})$ and the activation energy according to Equation (6).

\begin{tabular}{cccccc}
\hline Sample & Step & Range of Temperature $\left({ }^{\circ} \mathbf{C}\right)$ & $\mathbf{W L P}(\%) *$ & $\boldsymbol{E}_{\boldsymbol{a}}(\mathbf{k J} / \mathbf{m o l})$ & $\boldsymbol{k}_{\mathbf{0}}\left(\mathbf{s}^{-\mathbf{1}}\right)$ \\
\hline \multirow{3}{*}{ Alumina } & $1 \mathrm{st}$ & $26-113$ & 13.0 & 39.10 & $2.74 \times 10^{5}$ \\
& $2 \mathrm{nd}$ & $113-376$ & 18.0 & 6.11 & 6.14 \\
& $3 \mathrm{rd}$ & $376-495$ & 20.3 & 34.30 & $1.11 \times 10^{3}$ \\
\hline \multirow{3}{*}{$\mathrm{Fe} / \mathrm{Al}_{2} \mathrm{O}_{3} 0.5 \%$} & $1 \mathrm{st}$ & $26-121$ & 10.0 & 21.90 & $7.69 \times 10^{2}$ \\
& $2 \mathrm{nd}$ & $121-372$ & 15.5 & 7.06 & 7.07 \\
& $3 \mathrm{rd}$ & $372-496$ & 17.7 & 31.87 & 5.77 \\
\hline \multirow{3}{*}{$\mathrm{Pt} / \mathrm{Al}_{2} \mathrm{O}_{3} 0.5 \%$} & $1 \mathrm{st}$ & $27-113$ & 6.7 & 24.72 & $2.92 \times 10^{5}$ \\
& $2 \mathrm{nd}$ & $113-365$ & 12.0 & 7.28 & 6.02 \\
& $3 \mathrm{rd}$ & $365-496$ & 14.8 & 36.65 & $1.58 \times 10^{3}$ \\
$\mathrm{Pt}-\mathrm{Fe} / \mathrm{Al}_{2} \mathrm{O}_{3} 0.5 \%-0.5 \%$ & 2nd & $29-114$ & 5.0 & 17.00 & 12.0 \\
& $3 \mathrm{rd}$ & $114-370$ & 10.8 & 5.63 & 0.357 \\
& & $370-495$ & 13.7 & 8.20 & 0.543 \\
\hline
\end{tabular}

Using the heating rate expression is as follows:

$$
\mathrm{N}=\mathrm{d} T / \mathrm{d} t
$$

The equation can be resolved into the differential Equation (4):

$$
\ln [-\ln (1-\alpha)]=\ln k_{0}-\left(E_{a} / \mathrm{R} T\right)
$$

This method is known as Broido's method [50].

Figure 6 displays the experimental TGA data treated using Equation (6), and the activation energy values for each step are reported in Table 2 . The low activation energies (less than $10 \mathrm{kcal} / \mathrm{mol}$ $\approx 41.84 \mathrm{~kJ} / \mathrm{mol}$ ) indicate that a transport mechanism is more prevalent than the entirely reactive mechanism [50]. The first step for pure alumina has activation energy of $39.10 \mathrm{~kJ} / \mathrm{mol}$. This value decreases when platinum or iron are incorporated into the alumina, with values more than $50 \%$ lower 
when both platinum and iron are incorporated. For the second step, the activation energies for all of the samples are below $8 \mathrm{~kJ} / \mathrm{mol}$, indicating the mechanism is entirely physical. During the third step, the activation energy of every sample exceeds $30 \mathrm{~kJ} / \mathrm{mol}$ except for the bimetallic oxide sample $(8.20 \mathrm{~kJ} / \mathrm{mol})$. Activation energies near $40 \mathrm{~kJ} / \mathrm{mol}$ suggest a mechanism that involves breaking chemical bonds but are still far below the values needed for pyrolysis degradation [50]. The sample containing platinum and iron oxides display a physical-type desorption throughout the entire temperature range. Sitthisa et al. [51] present a model of the Langmuir-Hinshelwood kinetics for the hydrogenation of furfural over $\mathrm{Cu} / \mathrm{SiO}_{2}$; the equilibrium adsorption constant (that considers adsorption and desorption) falls from 0.29 to 0.08 torr $^{-1}(-72 \%)$ from 230 to $290{ }^{\circ} \mathrm{C}$. Even the test is different for our $\mathrm{Pt}-\mathrm{Fe} / \mathrm{Al}_{2} \mathrm{O}_{3}$ 0.5\%-0.5\% sample; the desorption constant never falls more than $14 \%$ from 25 to $495{ }^{\circ} \mathrm{C}$ (see Table 2). From the second step to the third, the bimetallic catalyst displays a slight increase (3\%) in the $k_{0}$ constant, indicating there are different interactions between the molecule and the support during each stage [47]. During the second step, the slower furfural release and the smaller $k_{0}$ reveal a more stable interaction.

Figure 6. Experimental data for alumina (-), $\mathrm{Fe} / \mathrm{Al}_{2} \mathrm{O}_{3} 0.5 \%(-), \mathrm{Pt}_{\mathrm{Al}} \mathrm{O}_{2} \mathrm{O}_{3} 0.5 \%(-)$ and $\mathrm{Pt}-\mathrm{Fe} / \mathrm{Al}_{2} \mathrm{O}_{3} 0.5 \%-0.5 \%$ (-) samples treated according Equation (6).

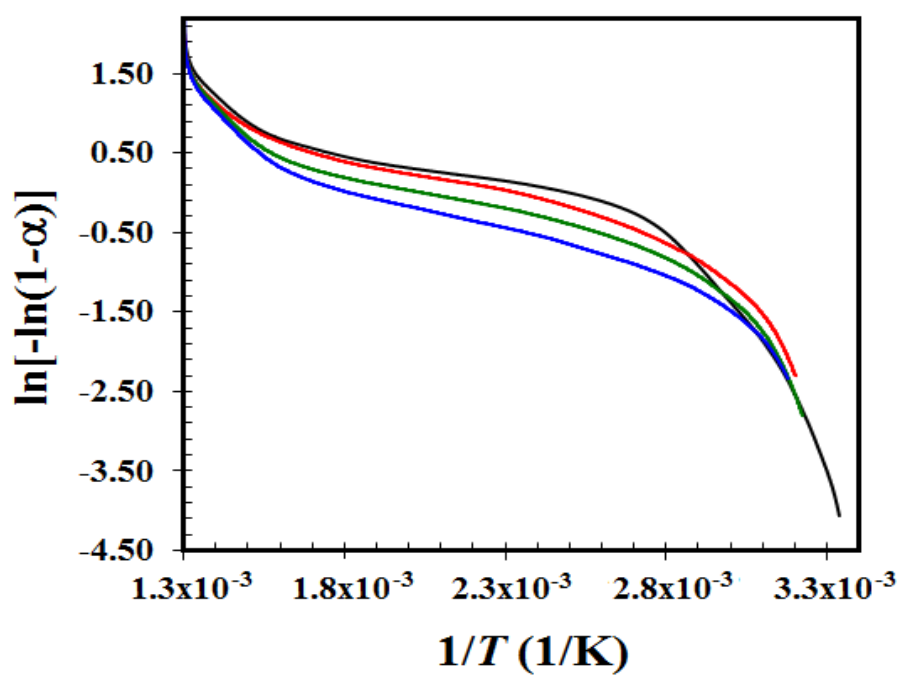

\subsection{FT-IR Spectra of Furfural Desorption on Pt-Fe/Al ${ }_{2} \mathrm{O}_{3}$ 0.5\%-0.5\%}

Because the bimetallic sample contains the most stable furfural species during desorption, the FT-IR spectra are studied at different temperatures during furfural desorption. Furfural contains two $\mathrm{O}$ atoms, one in the carbonyl group and one in the aromatic ring. These two atoms that are the possible adsorption points in furfural, and they are $2.809 \AA$ apart. At the molecular level, the adsorption configurations of furfural on the surfaces can be divided into three types: (a) parallel-ring adsorption, where the furfural molecule is roughly parallel to the surface; (b) carbonyl adsorption, where the $\mathrm{C}=\mathrm{O}$ bond is involved in the interaction with the surface and (c) perpendicular adsorption, where the furfural molecule is approximately perpendicular to a crystalline surface plane [51]. The strong interaction of the $\mathrm{O}$ atom in the carbonyl group on furfural and the other aldehydes on different surfaces has been studied, and their signals in the FT-IR spectra indicate weak energy interactions, generally from 1300 to $2100 \mathrm{~cm}^{-1}$. These aldehydes tend to form surface intermediates in which only the carbonyl $\mathrm{O}$ can be 
adsorbed on one metal atom (i.e., $\eta^{1}(\mathrm{O})$ ) or both $\mathrm{C}$ and $\mathrm{O}$ interact with the surface (i.e., $\eta^{2}(\mathrm{C}, \mathrm{O})$ ). For example, while the $\eta^{2}(\mathrm{C}, \mathrm{O})$ state is preferred on clean Pd surfaces, the $\eta^{1}(\mathrm{O})$ state is preferred when oxygen is present [52,53]. Therefore, the adsorption of $\eta^{1}(\mathrm{O})$ may be more likely in our samples. Figure 7 displays the FT-IR spectra for furfural desorbing at different temperatures from the $\mathrm{Pt}-\mathrm{Fe} / \mathrm{Al}_{2} \mathrm{O}_{3} 0.5 \%-0.5 \%$ sample. The band at $1635 \mathrm{~cm}^{-1}$ in the pure catalyst sample is associated with the $\mathrm{OH}$ groups of the $\mathrm{\gamma}$-alumina support, but this band is widened, forming a peak at $1602 \mathrm{~cm}^{-1}$ with a shoulder at $1569 \mathrm{~cm}^{-1}$ from 25 to $200{ }^{\circ} \mathrm{C}$ in the furfural-adsorbed samples. These bands are attributed to chemisorbed furfural, while the band at $1732 \mathrm{~cm}^{-1}$ is associated with the physisorbed furfural [4] that nearly disappears at $300{ }^{\circ} \mathrm{C}$, appears again at $350{ }^{\circ} \mathrm{C}$ and tends to disappear again at $450{ }^{\circ} \mathrm{C}$. The bands at 1486 and $1438 \mathrm{~cm}^{-1}$ that disappear at $300{ }^{\circ} \mathrm{C}$ are associated with the vibrations of the furan ring double bond. The band at $1371 \mathrm{~cm}^{-1}$ from 25 to $250{ }^{\circ} \mathrm{C}$ may be related to the oxidized $\eta^{2}(\mathrm{C}, \mathrm{O})$ $\left(v_{\mathrm{s}}(\mathrm{OCO})\right)$ species [6], revealing an interaction with oxygen from an oxide species on the catalyst, together with a strong interaction existing between metallic species, according to the TPR and TEM results. This interaction warrants a discussion regarding the type of acidity present in the catalyst because the carbonyl oxygen from furfural is Lewis basic and is therefore capable of sharing a pair of electrons; consequently, Lewis acidic sites must also exist in the catalyst for this bond to be formed.

Figure 7. FT-IR spectra furfural desorption at different temperatures in the Pt-Fe/ $/ \mathrm{Al}_{2} \mathrm{O}_{3}$ $0.5-0.5 \%$ sample.

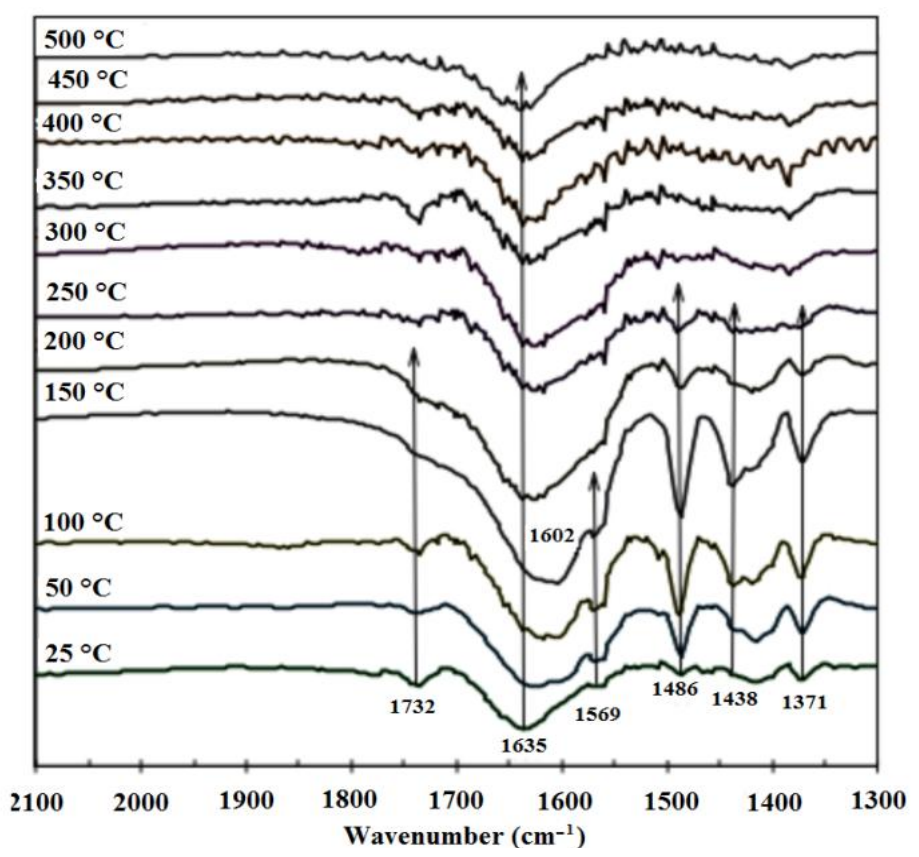

The liquid impregnated furfural almost completely disappears at $200{ }^{\circ} \mathrm{C}$, but some bands remain detectable from 300 to $450{ }^{\circ} \mathrm{C}$, validating the TGA/DTA data. No band appears at $\sim 1957 \mathrm{~cm}^{-1}$ to indicate $\mathrm{CO}$ adsorption from thermally decarboxylated furfural [4], revealing the favorably improved stability of furfural on our bimetallic sample. 


\section{Experimental Section}

\subsection{Synthesis of Catalysts}

The CATALOX ${ }^{\circledR}$ (Houston, TX, USA) $\gamma$-alumina, $\mathrm{FeCl}_{3}$ and $\mathrm{PtCl}_{2}$ (by Sigma-Aldrich, St. Louis, MO, USA) were mixed in water, the cationic concentration of the solution was adjusted to $0.5 \mathrm{wt} \%$ on the alumina and the solution was stirred for $24 \mathrm{~h}$. The water was subsequently evaporated at $80{ }^{\circ} \mathrm{C}$, and the catalyst was calcined at $600{ }^{\circ} \mathrm{C}$. The catalysts were prepared in the following compositions: $\mathrm{Fe} / \mathrm{Al}_{2} \mathrm{O}_{3} 0.5 \%, \mathrm{Pt} / \mathrm{Al}_{2} \mathrm{O}_{3} 0.5 \%$ and $\mathrm{Pt}-\mathrm{Fe} / \mathrm{Al}_{2} \mathrm{O}_{3} 0.5 \%-0.5 \%$.

\subsection{Characterization Techniques}

The specific surface areas of the samples were determined using $\mathrm{N}_{2}$ physisorption at $77.3 \mathrm{~K}$ with a Quantachrome-NovaWin2 (Boynton Beach, FL, USA). SEM photomicrographs were obtained with a FEI Nova Nano SEM 200 (FEI, Hillsboro, OR, USA) at $20 \mathrm{kV}$ at a $1 \mathrm{~nm}$ resolution. The working distance and energy dispersive spectra (EDS) were collected using an EDAX Genesis XM4 detector for elemental analysis (EDAX Inc, Mahwah, NJ, USA) A FEI Titan G2 30-800 microscope was used for high-resolution transmission electron microscopy (HRTEM) imaging. The FT-IR spectra were measured on a Nicolet 6700 spectrometer (FEI), for samples in mixed $\mathrm{KBr}$ disks. The temperature-programmed reduction (TPR) of the catalysts was carried in flowing a $10 \% \mathrm{H}_{2} / \mathrm{Ar}$ mixture at $30 \mathrm{~mL} / \mathrm{min}$ with heating at $5{ }^{\circ} \mathrm{C} / \mathrm{min}$. Before the analysis, the catalysts were pretreated in argon at $300{ }^{\circ} \mathrm{C}$ for $30 \mathrm{~min}$. The hydrogen consumption was monitored using the thermal conductivity detector with mass spectrometry capabilities using an Altamira Instruments model AMI 90 (Altamira Instruments Inc, Pittsburgh, PA, USA).

For the desorption tests, all catalysts were impregnated with $30 \%$ (total weight) of furfural, with the following quantities: alumina; $0.401 \mathrm{~g}$ of powder and $0.170 \mathrm{~g}$ of furfural $(29.77 \%), \mathrm{Fe} / \mathrm{Al}_{2} \mathrm{O}_{3} ; 0.504 \mathrm{~g}$ of powder and $0.218 \mathrm{~g}$ of furfural $(30.19 \%), \mathrm{Pt} / \mathrm{Al}_{2} \mathrm{O}_{3} ; 0.401 \mathrm{~g}$ of powder and $0.175 \mathrm{~g}$ of furfural (30.38\%), Pt-Fe/ $/ \mathrm{Al}_{2} \mathrm{O}_{3} ; 0.412 \mathrm{~g}$ of powder and $0.178 \mathrm{~g}$ of furfural (30.17). The excess of furfural was desorbed at room temperature for $10 \mathrm{~min}$. The catalysts were then analyzed by TGA/DTA using a TA Instruments SDT-2960 thermal analyzer, with a temperature slope of $5{ }^{\circ} \mathrm{C} / \mathrm{min}$, from 25 to $500{ }^{\circ} \mathrm{C}$ in $\mathrm{N}_{2}$ with a flow of $100 \mathrm{~mL} / \mathrm{min}$.

\section{Conclusions}

The desorption of furfural on samples of pure alumina and samples with $0.5 \% \mathrm{Fe}$ and $0.5 \%-5 \% \mathrm{Pt}$ oxides was studied; the bimetallic sample exhibited the best thermal properties and resistance toward furfural desorption. The $\mathrm{Pt}$ oxide species, such as $\mathrm{PtO}$ and $\mathrm{Pt}_{6} \mathrm{O}_{8}$, were identified in the HRTEM images, and magemite, maghemite and hematite phases of iron oxide were also identified. Both types of crystalline oxides were intimately connected on the alumina support. The FT-IR studies indicated that impregnating both metallic oxides affected the tetrahedral $\left(\mathrm{AlO}_{4}\right)$ and octahedral $\left(\mathrm{AlO}_{6}\right)$ sites of the alumina. The TPR results revealed that $\mathrm{Fe}$ and $\mathrm{Pt}$ are present over the catalyst surface as iron oxides and Pt oxy- or hydroxychlorinated species. The TPR results were in agreement with the HRTEM analysis because both suggested that a strong interaction characteristic of alloys was present 
between $\mathrm{Pt}$ and $\mathrm{Fe}$ and that different $\mathrm{Pt}$ and Fe species are present with different shapes, sizes and structures across the catalyst surface. For the pure alumina and the samples impregnated both single and bimetallic $\mathrm{Fe}$ and $\mathrm{Pt}$ oxides, the mechanism of desorption from approximately $113{ }^{\circ} \mathrm{C}$ to approximately $370{ }^{\circ} \mathrm{C}$ tended to be more like physisorption. The mechanism for the temperatures below $113{ }^{\circ} \mathrm{C}$ and above $370{ }^{\circ} \mathrm{C}$ resembled chemical desorption, based on the activation energy values obtained during the TGA tests. The Pt-Fe/ $/ \mathrm{Al}_{2} \mathrm{O}_{3}$ 0.5\%-0.5\% sample exhibited no significant changes in the low energies of activation over the complete temperature range, demonstrating a more homogenous mechanism of desorption. The FT-IR spectra at different temperatures during the furfural desorption from the Pt-Fe/ $/ \mathrm{Al}_{2} \mathrm{O}_{3}$ 0.5\%-0.5\% sample revealed both chemisorption and physisorbtion interactions, but the aldehyde radical of furfural and the specific $\eta^{2}(\mathrm{C}, \mathrm{O})$ interaction with the surface revealed the formation of oxide species (OCO) with the sample. The bimetallic Fe-Pt oxide sample is a good catalyst that stabilizes the adsorbed furfural molecule for subsequent reactions.

\section{Acknowledgment}

This work was funded by Facultad de Ciencias Químicas, UANL and CONACYT 167729.

\section{Conflicts of Interest}

The authors declare no conflict of interest.

\section{References}

1. Kamm, B.; Gruber, P.R.; Kamm, M. Biorefineries-Industrial Processes and Products Status Quo and Future Directions, 1st ed.; Wiley-VCH: Weinheim, Germany, 2006.

2. Sádaba, I.; Ojeda, M.; Mariscal, R.; Fierro, J.L.G.; López Granados, M. Catalytic and structural properties of co-precipitated $\mathrm{Mg}-\mathrm{Zr}$ mixed oxides for furfural valorization via aqueous aldol condensation with acetone. Appl. Catal. B 2011, 101, 638-648.

3. Fanchiang, W.L.; Lin, Y.C. Catalytic fast pyrolysis of furfural over H-ZSM-5 and Zn/H-ZSM-5 catalysts. Appl. Catal. A Gen. 2012, 419-420, 102-110.

4. Zhang, W.; Zhu, Y.; Niu, S.; Li, Y. A study of furfural decarbonylation on K-doped $\mathrm{Pd} / \mathrm{Al}_{2} \mathrm{O}_{3}$ catalysts. J. Mol. Catal. 2011, 335, 71-81.

5. Resasco, D.E.; Sitthisa, S. Hydrodeoxygenation of furfural over supported metal catalysts: A comparative study of $\mathrm{Cu}, \mathrm{Pd}$ and Ni. Catal. Lett. 2011, 141, 784-791.

6. An, W.; Sitthisa, S.; Resasco, D.E. Selective conversion of furfural to methylfuran over silica-supported Ni/Fe bimetallic catalysts. J. Catal. 2011, 284, 90-101.

7. West, R.M.; Liu, Z.Y.; Peter, M.; Dumesic, J.A. Liquid alkanes with targeted molecular weights from biomass-derived carbohydrates. Sustain. Chem. 2008, 1, 417-424.

8. Rojas, H.; Borda, G.; Rosas, D.; Martinez, J.J.; Reyes, P. Hydrogenation of furfural on $\mathrm{Ir} / \mathrm{Nb}_{2} \mathrm{O}_{5}$ catalyst study kinetic. Dyna 2008, 155, 115-122.

9. Ragaini, V.; Pirola, C.; Vitali, S.; Bonura, G.; Cannilla, C.; Frusteri, F. Stability of metallic ruthenium in Ru-Co supported silica catalysts. Catal. Lett. 2012, 142, 1452-1460. 
10. Méndez, F.J.; Bastardo-González, E.; Betancourt, P.; Paiva, L.; Brito, J.L. NiMo/MCM-41 catalysts for the hydrotreatment of polychlorinated biphenyls. Catal. Lett. 2013, 143, 93-100.

11. Sun, Y.N.; Qin, Z.H.; Lewandowski, M.; Kaya, S.; Shaikhutdinov, S.; Freund, H.J. When an encapsulating oxide layer promotes reaction on noble metals: Dewetting and in situ formation of an "Inverted" $\mathrm{FeO}_{x} / \mathrm{Pt}$ catalyst. Catal. Lett. 2008, 126, 31-35.

12. Yu, W.; Porosoff, M.D.; Chen, J.G. Review of Pt-based bimetallic catalysis: From model surfaces to supported catalysts. Chem. Rev. 2012, 112, 5780-5817.

13. Vetere, V.; Merlo, A.B.; Ruggera, J.F.; Casella, M.L.; Braz, J. Transition metal-based bimetallic catalysts for the chemoselective hydrogenation of furfuraldehyde. Chem. Soc. 2010, 21, 914-920.

14. Zheng, H.Y.; Zhu, Y.; Huang, L.; Zeng, Z. Study on Cu-Mn-Si catalysts for synthesis of cyclohexanone and 2-methylfuran through the coupling process. Catal. Commun. 2008, 9, 342-348.

15. Wu, J.; Shen, Y.M.; Liu, C.H.; Wang, H.B.; Geng, C.J.; Zhang, Z.X. Vapor phase hydrogenation of furfural to furfuryl alcohol over environmentally friendly $\mathrm{Cu}-\mathrm{Ca} / \mathrm{SiO}_{2}$ catalyst. Catal. Commun. 2005, 6, 633-637.

16. Lucio-Ortiz, C.J.; de la Rosa, J.R.; Ramirez, A.H.; Heredia, J.A.D.; Del Angel, P.; Muñoz-Aguirre, S.; de León-Covián, L.M. Synthesis and characterization of Fe doped mesoporous $\mathrm{Al}_{2} \mathrm{O}_{3}$ by sol-gel method and its use in trichloroethylene combustion. J. Sol.-Gel. Sci. Technol. 2011, 58, 374-384.

17. Rachmady, W.; Vannice, M.A. Acetic acid reduction by $\mathrm{H}_{2}$ on bimetallic Pt-Fe catalysts. J. Catal. 2002, 209, 87-98.

18. Ma, T.; Fu, Q.; Su, H.; Liu, H.; Cui, Y.; Wang, Z.; Mu, R.; Li, W.; Bao, X. Reversible structural modulation of Fe-Pt bimetallic surfaces and its effect on reactivity. Chem. Phys. Chem. 2009, 10, 1013-1016.

19. Meng, Z.; Liu, H.; Liu, Y.; Zhang, J.; Yu, S.; Cui, F.; Ren, N.; Ma. J. Preparation and characterization of $\mathrm{Pd} / \mathrm{Fe}$ bimetallic nanoparticles immobilized in $\mathrm{PVDF} \cdot \mathrm{Al}_{2} \mathrm{O}_{3}$ membrane for dechlorination of monochloroacetic acid. J. Memb. Sci. 2001, 372, 165-171.

20. Kobayashi, S.; Kaneko, S.; Ohshima, M.; Kurokawa, H.; Miura, H. Effect of iron oxide on isobutane dehydrogenation over $\mathrm{Pt} / \mathrm{Fe}_{2} \mathrm{O}_{3}-\mathrm{Al}_{2} \mathrm{O}_{3}$ catalyst. Appl. Catal. 2012, 417-418, 306-312.

21. Popat, A.; Liu, J.; Lu, G. Q.; Qiao, S.Z. A pH-responsive drug delivery system based on chitosan coated mesoporous silica nanoparticles. J. Mater. Chem. 2012, 22, 11173-11178.

22. Lin, C.X.; Yuan, P.; Yu, C.Z.; Qiao, S.Z.; Lu, G.Q. Cooperative self-assembly of silica-based mesostructures templated by cationic fluorocarbon/hydrocarbon mixed-surfactants. Microporous Mesoporous Mater. 2009, 126, 253-261.

23. Usai, E.M.; Sini, M.F.; Meloni, D.; Solinas, V.; Salis, A. Sulfonic acid-functionalized mesoporous silicas: Microcalorimetric characterization and catalytic performance toward biodiesel synthesis. Microporous Mesoporous Mater. 2013, 179, 54-62.

24. Baeissa, E.S.; Mohamed, R.M. $\mathrm{Pt} / \mathrm{Ga}_{2} \mathrm{O}_{3}-\mathrm{SiO}_{2}$ nanoparticles for efficient visible-light photocatalysis. Ceram. Int. 2014, 40, 841-847.

25. Esparza, J.M.; Ojeda, M.L.; Campero, A.; Hernández, G.; Felipe, C.; Asomoza, M.; Cordero, S.; Kornhauser, I.; Rojas, F. Development and sorption characterization of some model mesoporous and microporous silica adsorbents. J. Mol. Catal. Chem. 2005, 228, 97-110. 
26. Seshu Babu, N.; Lingaiah, N.; Sai Prasad, P.S. Characterization and reactivity of $\mathrm{Al}_{2} \mathrm{O}_{3}$ supported Pd-Ni bimetallic catalysts for hydrodechlorination of chlorobenzene. Appl. Catal. 2012, 111-112, 309-316.

27. Huang, C.; Wang, I.; Lin, Y.; Tseng, Y.; Lu, C. Visible light photocatalytic degradation of nitric oxides on $\mathrm{PtO}_{x}$-modified $\mathrm{TiO}_{2}$ via sol-gel and impregnation method. J. Mol. Catal. Chem. 2010, $316,163-170$.

28. Croy, J.R.; Mostafa, S.; Hickman, L.; Heinrich, H.; Roldan Cuenya, B. Bimetallic Pt-Metal catalysts for the decomposition of methanol: Effect of secondary metal on the oxidation state, activity, and selectivity of Pt. Appl. Catal. 2008, 350, 207-216.

29. Sunagawa, Y.; Yamamoto, K.; Takahashi, H.; Muramatsu, A. Liquid-phase reductive deposition as a novel nanoparticle synthesis method and its application to supported noble metal catalyst preparation. Catal. Today 2008, 132, 81-87.

30. Bora, D.K.; Braun, A.; Erat, S.; Safonova, O.; Graule, T.; Constable, E.C. Evolution of structural properties of iron oxide nano particles during temperature treatment from $250{ }^{\circ} \mathrm{C}-900{ }^{\circ} \mathrm{C}$ : X-ray diffraction and Fe K-shell pre-edge X-ray absorption study. Curr. Appl. Phys. 2012, 12, 817-825.

31. Daniel, D.W. Infrared studies of $\mathrm{CO}$ and $\mathrm{CO}_{2}$ Adsorption on $\mathrm{Pt} / \mathrm{CeO}_{2}$ : The characterization of active sites. J. Phys. Chem. 1988, 92, 3891-3899.

32. Bazin, P.; Saur, O.; Marie, O.; Daturi, M.; Lavalley, J.C.; Le Govic, A.M.; Harlé, V.; Blanchar, G. On the reducibility of sulfated $\mathrm{Pt} / \mathrm{Ce}_{X} \mathrm{Zr}_{1-X} \mathrm{O}_{2}$ solids: A coupled thermogravimetric FT-IR study using CO as the reducing agent. Appl. Catal. 2012, 119-120, 207-216.

33. Tabor, E.; Jiša, K.; Novakova, J.; Bastl, Z.; Vondrová, A.; Závêta, K.; Sobalík, Z. Role of Pt(0) in bimetallic $(\mathrm{Pt}, \mathrm{Fe})-\mathrm{FER}$ catalysts in the $\mathrm{N}_{2} \mathrm{O}$ decomposition. Microporous Mesoporous Mater. 2013, 65, 40-471.

34. Korányi, T.I.; Mihály, J.; Pfeifer, É.; Németh, C.; Yuzhakova, T.; Mink, J. Infrared emission and theoretical study of carbon monoxide adsorbed on alumina-supported $\mathrm{Rh}$, Ir and $\mathrm{Pt}$ catalysts. J. Phys. Chem. 2006, 110, 1817-1823.

35. Dablemont, C.; Lang, P.; Mangeney, C.; Piquemal, J.; Petkov, V.; Herbst, F.; Viau, G. FTIR and XPS study of Pt nanoparticle functionalization and interaction with alumina. Langmuir 2008, 24 , 5832-5841.

36. Keresszegi, C.; Ferri, D.; Mallat, T.; Baiker, A. On the role of $\mathrm{CO}$ formation during the aerobic oxidation of alcohols on $\mathrm{Pd} / \mathrm{Al}_{2} \mathrm{O}_{3}$ : An in situ attenuated total reflection infrared study. J. Catal. 2005, 234, 64-75.

37. Montanari, T.; Castoldi, L.; Lietti, L.; Busca, G. Basic catalysis and catalysis assisted by basicity: FT-IR and TPD characterization of potassium-doped alumina. Appl. Catal. Gen. 2011, 400, 61-69.

38. Darezereshki, E. One-step synthesis of hematite $\left(\alpha-\mathrm{Fe}_{2} \mathrm{O}_{3}\right)$ nano-particles by direct thermal-decomposition of maghemita. Mater. Lett. 2011, 65, 642-645.

39. Lingaiah, N.; Sai Prasad, P.S.; Kanta Rao, P.; Berry, F.J.; Smart, L.E. Structure and activity of microwave irradiated silica supported Pd-Fe bimetallic catalysts in the hydrodechlorination of chlorobenzene. Catal. Commun. 2002, 3, 391-397.

40. Liang, M.; Kang, W.; Xie, K. Comparison of reduction behavior of $\mathrm{Fe}_{2} \mathrm{O}_{3}, \mathrm{ZnO}$ and $\mathrm{ZnFe}_{2} \mathrm{O}_{4}$ by TPR technique. J. Nat. Gas Chem. 2009, 18, 110-113. 
41. Munteanu, G.; Ilieva, L.; Andreeva, D. Kinetic parameters obtained from TPR data for $\alpha-\mathrm{Fe}_{2} \mathrm{O}_{3}$ and $\mathrm{Au} / \alpha-\mathrm{Fe}_{2} \mathrm{O}_{3}$ systems. Therrnochim. Acta 1997, 291, 171-177.

42. Mazzieri, V.A.; Grau, J.M.; Yori, J.C.; Vera, C.R.; Pieck, C.L. Influence of additives on the Pt metal activity of naphtha reforming catalysts. Appl. Catal. Gen. 2009, 354, 161-168.

43. Contreras-Andrade, I.; Vázquez-Zavala, A.; Viveros, T. Influence of the synthesis method on the catalytic behavior of $\mathrm{Pt}$ and $\mathrm{PtSn} / \mathrm{Al}_{2} \mathrm{O}_{3}$ reforming catalyst. Energ. Fuel 2009, 23, 3835-3841.

44. Tian, D.; Liu, Z.; Li, D.; Shi, H.; Pan, W.; Cheng, Y. Bimetallic Ni-Fe total-methanation catalyst for the production of substitute natural gas under high pressure. Fuel 2013, 104, 224-229.

45. Kugai, J.; Miller, J.T.; Guo, N.; Song, C. Oxygen-enhanced water gas shift on ceria-supported $\mathrm{Pd}-\mathrm{Cu}$ and $\mathrm{Pt}-\mathrm{Cu}$ bimetallic catalysts. J. Catal. 2011, 277, 46-53.

46. Pojanavaraphan, C.; Luengnaruemitchai, A.; Gulari, E. Catalytic activity of $\mathrm{Au}-\mathrm{Cu} / \mathrm{CeO}_{2}-\mathrm{ZrO}_{2}$ catalysts in steam reforming of Methanol. Appl. Catal. Gen. 2013, 456, 135-143.

47. Vorotnikov, V.; Mpourmpakis, G.; Vlachos, D.G.; DFT study of furfural conversion to furan, furfuryl alcohol, and 2-methylfuran on Pd(111). ACS Catal. 2012, 2, 2496-2504.

48. Pang, S.H.; Medlin, J.W. Adsorption and reaction of furfural and furfuryl alcohol on $\operatorname{Pd}(111)$ : Unique reaction pathways for multifunctional reagents. ACS Catal. 2011, 1, 1272-1283.

49. Cozic, C.; Picton, L.; Garda, M.; Marlhoux, F.; le Cerf, D. Analysis of arabic gum: Study of degradation and water desorption processes. Food Hydrocoll. 2009, 23, 1930-1934.

50. Broido, A. A simple, sensitive graphical method of treating thermogravimetric analysis data. J. Polym. Sci. Polym. Chem. 1969, 7, 1761-1773.

51. Sitthisa, S.; Sooknoi, T.; Ma, Y.; Balbuena, P.B.; Resasco, D.E. Kinetics and mechanism of hydrogenation of furfural on $\mathrm{Cu} / \mathrm{SiO}_{2}$ catalysts. J. Catal. 2011, 277, 1-13.

52. Davis, J.L.; Barteau, M.A. Polymerization of decabonylation reactions of aldheydes on the Pt(111) surface. J. Am. Chem. Soc. 1989, 111, 1782-1792.

53. Davis, J.L.; Barteau, M.A. The interactions of oxygen with aldehydes on the $\operatorname{Pd}(111)$ surface. Surf. Sci. 1992, 268, 11-24.

(C) 2014 by the authors; licensee MDPI, Basel, Switzerland. This article is an open access article distributed under the terms and conditions of the Creative Commons Attribution license (http://creativecommons.org/licenses/by/3.0/). 